\title{
CAMINO DE LOS ESPAÑOLES
}

\author{
LENA YAU
}

\author{
A Gabriela Keller que guarda y vela al mar Caribe por mi. \\ A Alejandro Medina que sueña con Tucacas en la calle Rios Rosas.
}

\begin{abstract}
¿Sabes? Yo tenía un arpón buenísimo que me traje de Caracas pero le di tanta rosca que llegó roto y no quise comprar otro. Madrid no tiene mar pero no importa, chico, la M-30 es como la Francisco Fajardo, imagina que el Guaire está soterrado y piensa que Madrid se divide en dos, de la M-30 para allá y de la M-30 para acá. Igualito que Caracas: del río para allá y del río para acá. No tiene Ávila, es cierto, pero puedes pensar que la sierra es como si fuera el cerro. Y esa nieve no es nieve, son nubes. Y la plaza Santa Ana es La Candelaria, aunque nadie entienda por qué pides aceite de oliva y Tío Pepe para bañar la paella. Madrid trasmutada en Caracas para consolarme, para aliviar el despecho por el arpón perdido, el guayabo por lo que dejé. Iba bien en mi proceso de adaptación hasta el día que cogí la M-30 buscando ir a Toledo. Mientras conducía olvidé quién era, qué hacía allí, a dónde iba. Sentía las manos imantadas al volante. No lograba coordinar las piernas. Pensé en parar, pedir ayuda, pero no sabía cómo. La policía me encontró aparcado a mitad de la autopista, sin gasolina en el tanque y sin habla en la garganta. Me hicieron la prueba de alcoholemia, me tomaron la tensión. Hablaron de un acv leve, de fatiga. Me regresaron a casa. El coche lo recogí un mes después en un depósito. Repetí el viaje y sucedió lo mismo. Eso sí, tomé precauciones. Le dije a un pana que me acompañara y que manejara él. Apenas pasamos el cartel que da la bienvenida a Castilla La Mancha dejé de estar en mí. Juanjo estaba advertido. Se detuvo en un bar. Me sentó en una mesa. Pidió un sol y sombra y me lo hizo beber. Yo seguía ausente. Se tomó un café cargado, jugó un par de monedas en la tragaperras y subimos al coche de vuelta a casa. Cuando llegamos a mi portal me bajé sin hacer preguntas. Sólo le dije que me dolía la cabeza.
\end{abstract}

Esa noche recordé a mi padre. Papá aclimatado al trópico. Papá amando el mar Caribe. Papá recitando por orden alfabético los peces de Venezuela. Papá riendo cuando los amigos canarios lo llamaban godo. Un día le pregunté ¿por qué godo? y me respondió con un libro. No lo leí en ese momento. Lo guardé y lo volví a ver cuando desempaqué mis cosas al mudarme a Madrid. Cuaderno de Godo de Ignacio Aldecoa. Lo busqué en la balda que comparte con los elepés de Frank Zappa y Rush y lo hojeé por pasar el rato, sin curiosidad, hasta que en una frase se hizo la luz: Una isla es un paréntesis en la monotonía del mar, como un lago es un paréntesis en la monotonía de la tierra. Esa era la explicación a mis brotes catatónicos. Refugiado en una isla imaginaria pero con necesidad de agua. Al zarpar de la isla que me había inventado no encontraba mar sino una meseta árida. Rehíce mentalmente la ruta que había recorrido en la mańana. Salgo de Madrid y dejo atrás extensiones de adosados, 
grandes superficies, ciudades dormitorios, fincas con restaurantes temáticos para bodas, bautizos y comuniones, outlets, importadoras chinas, iteuves, colegios bilingües y europeos, universidades de nuevo cuño, polígonos industriales, puticlubs, circuitos de karts, viveros, dehesas con ovejas y vacas, la tierra asoma ríspida, anfractuosa, una llanura color arcilla salpicada de verdes puntuales. Cruzo la altiplanicie ondulante, ruedo hacia un puerto, siento presión en los oídos, me aproximo al punto más alto, el cielo se va agrandando, mi cuello se estira tenso buscando un horizonte azul que no existe, en su lugar encuentra una línea terracota que se acerca según el coche avanza y se puebla de pinos, de la silueta del toro de Osborne, de molinos de viento de última generación, de las ruinas de un castillo y rompo a llorar al descubrir que esas subidas y bajadas también eran mi camino hacia el mar y lo que queda de una torre destruida en alguna guerra antigua me lleva a aquel castillo feísimo que colgaba de la montańa pasando Las Salinas, un horror arquitectónico que un alucinado mandó a construir, un mamotreto del que nos burlábamos con saña y que convertimos en referencia para los que se perdían en el camino, si ves el castillo vas bien, chamo, rueda largo, calcula media hora y a mano izquierda vas a encontrar un arco en el que se lee Villa Croacia, allí es, no te vayas a pasar que llegas a Chichiriviche de la costa... ¿recuerdas Carayaca?

Papá y Aldecoa eran pájaros de tierra en mar. Yo soy lo inverso. Los viajes de regreso nos hacen vestir la ropa al revés. Me rodea la tierra, tengo que buscar el agua. Como hizo el palmero alto amigo de mi padre. Ese hombre sabía de agua. Era el perfecto zahorí. Los ingenieros decían que no, que allí es imposible hablar de ríos subterráneos. El palmero se reía, daba dos pisotones y ordenaba: pongan la máquina aquí. No perdía tiempo en aforos. Aquí es. Dos pisotones más. A treinta metros está. Bajaba la mecha y a los veinte ya se sabía que el agua estaba. El palmero amaba el agua. Hizo de ella su modo de vida y ya no añoró regresar. Así que compré un local pequeño, abrí la librería y la llamé Tucacas imaginando que el nombre funcionaría como una horquilla de madera que señala el lugar exacto donde está enterrado lo que fue.

En un paso más por recuperar intenté ir a la costa a ver el mar. Juanjo no podía acompañarme, se echó una novia que pensaba que yo además de sudaca, era rarito. Mi hermana accedió a llevarme a cambio de que hiciera de canguro una noche para ella poder salir de marcha con su marido. Benidorm, dijo. Me negué. Quiero mar sin edificios. Pues coge un avión y vete para Araya, contestó. Acordamos un punto medio: Xavea. Fue un fin de semana estupendo. Paseamos por Alicante, Calpe, Moraira. Comimos pulpo seco y soparet. Compartimos olas con aguamalas gigantes. Mi hermana conoció la vida nocturna de Benidorm, se unió a una comparsa de enfermeras en minifalda y bailó en una discoteca de espuma. Eso me contaron. Yo caí en estupor al cruzar la frontera de la Comunidad de Madrid. Mi cuñado me dijo que no me lo tomara a mal, que cruzó los dedos para que me repitiera el yeyo porque no tenía ningunas ganas de salir de juerga con mi hermana. Él se quedó conmigo, con los niños y con la liga y Begoña salió por su cuenta.

De nuevo en casa volví a mi padre para guiarme. Tengo que listar los peces de Madrid para achulaparme. Tengo que sumergirme en agua cercana. Tengo que pescar. Investigando supe que dentro de la isla inventada había agua. No tendría que caer de nuevo 
en un precipicio que me pausaba: el agua que existía en la tierra que cruzaba mis límites tenía las propiedades del Leteo. El pantano de San Juan es seguro. Pertenece a la comunidad de Madrid. Barbo, blackbass, boga, carpa, lucio, percasol, me aprendí al caletre la posibilidad de la pesca y rompí mi furruco para hacer un arpón. Total, ¿cómo voy a armar un conjunto de gaitas aquí? ¿Qué hago con un furruco yo solo? Afilé el palo y lo dejé bien puyúo y con los cueros del tambor hice unas tiras y le amarré un puñal que tenía para despegar lapas. Quedó letal mi arpón casero. Me compré un traje de neopreno y me fui a la carretera de los pantanos. Llegué sin ataques. Entré en el agua y atravesé un par de peces lodosos y sin nombre. Regresé a Madrid sin salir de Madrid con mi memoria intacta. Desde entonces voy al pantano, hago inmersión desde la orilla con los ojos cerrados y espero. Pesco lucios porque suelen ser grandes. ¿Los has visto? Tienen la boca como un pato. Me ubico entre los árboles sumergidos. Cuando escucho un sonido parecido al de los cauchos rodando sobre la calle después de la lluvia sé que el lucio se acerca. Una vez que lo siento nadar sobre mi cabeza levanto con ganas el palo del furruco y lo ensarto. Si son medianos quedan clavados a la primera. Si son grandes, cuesta un poco más. Ella me trajo las fotos y la carta. Me sorprendió verla tantos ańos después. Me preguntó por qué pescaba si no me comía los peces y le contesté mentalmente: por el subidón de matar.

No nos dije la verdad.

Pesco por aquellos días.

Porque quería crecer para ser de vuestra pandilla.

Porque lejos de mi mar siento que soy como el tiburón que pescaste una vez y que disecado adornaba la pared de tu balcón en los Palos Grandes.

O como el Pez globo que el palmero tenía sobre el televisor.

Fuera del agua soy de cartón piedra y no respiro.

Lena Yau (Caracas, 1968). Narradora, poeta, periodista e investigadora.

Especialista en el vínculo entre literatura e ingesta. Licenciada en Letras y

Máster en Comunicación Social por la Universidad Católica Andrés Bello.

Investigadora y asesora literaria de El sabor de la eñe. Glosario de

literatura y gastronomía (Madrid: Instituto Cervantes, 2011). Autora de la

novela Hormigas en la lengua (Nueva York: Sudaquia, 2015). Autora del

poemario Trae tu espalda para hacer mi mesa (Madrid: Gravitaciones,

2015). Columnista en el diario El Nacional. Columnista en la revista

Climax. Reside en Madrid.

Twitter: @lenayau |Facebook: Lena Yau | Correo: lenayau@gmail.com

Blog: www.milorillas.blogspot.com | El Nacional: http://www.el-

nacional.com/autores/lena_yau/ 